\title{
Rapid emergence of temporal and pulvinar lesions in MELAS mimicking Creutzfeldt-Jakob disease
}

Figure MRI and spectroscopy
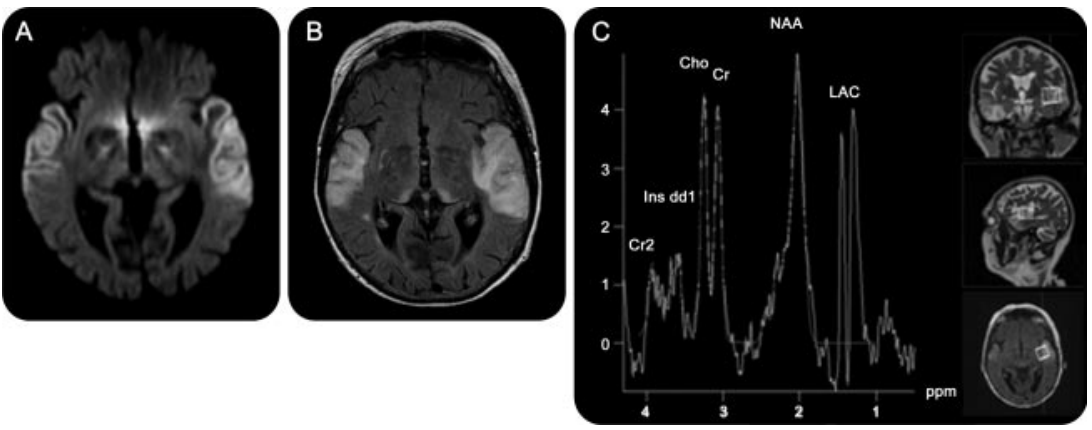

(A) The diffusion-weighted image displays bitemporal neocortical hyperintense signals. (B) The fluid-attenuated inversion recovery image 2 days after the initial MRI scan reveals newly emerging symmetric lesions in the pulvinar thalami. (C) Magnetic resonance spectroscopy displays a strong lactate signal.

Hyperintense areas in the pulvinar in fluid-attenuated inversion recovery images and greater hyperintensity in cortical areas in DWI are typical of sporadic Creutzfeldt-Jacob disease (sCJD). ${ }^{1}$ A 59-year-old woman developed confusion, progressive aphasia, mutism, and fluctuations of vigilance within 2 weeks. MRI revealed abnormalities consistent with sCJD (figure). CSF showed normal cell counts, negative PCR for HSV, elevated lactate $(4.6 \mathrm{mmol} / \mathrm{L})$, and increased levels of $14-3-3$ and tau protein $(1,300 \mathrm{pg} / \mathrm{L})$. There were no periodic sharp-wave complexes on EEG recordings. Magnetic resonance spectroscopy revealed a lactate signal indicative of mitochondriopathy ${ }^{2}$ and genetic analysis confirmed the MELAS A3243G mutation. Mitochondriopathies should be considered if otherwise typical features of SCJD rapidly emerge.

\section{Weiss, MD, K. Brockmann, MD, T. Nägele, MD, T. Gasser, MD, and R. Krüger, MD, Tübingen, Germany}

Author contributions: Dr. Weiss: drafting/revising the manuscript, study concept or design, analysis or interpretation of data, acquisition of data, study supervision. Dr. Brockmann: drafting/revising the manuscript, study concept or design, analysis or interpretation of data, acquisition of data. Dr. Nägele: analysis or interpretation of data, acquisition of data. Dr. Gasser: drafting/revising the manuscript, analysis or interpretation of data, study supervision, obtaining funding. Dr. Krüger: drafting/revising the manuscript, study concept or design, analysis or interpretation of data, study supervision.

Disclosure: Dr. Weiss has received funding for travel and speaker honoraria from Medtronic and Solvay Pharmaceuticals; and receives research support from Medtronic, Inc. and the University of Tübingen. Dr. Brockmann has received speaker honoraria from GlaxoSmithKline and Orion Corporation and funding for travel from GlaxoSmithKline, UCB, and the Movement Disorders Society. Dr. Nägele reports no disclosures. Dr. Gasser serves on the editorial boards of Parkinsonism and Related Disorders, Movement Disorders, and the Journal of Neurology; is author on a patent re: KASPP (LRRK2) gene, its production and use for the detection and treatment of neurodegenerative diseases; serves as a consultant for Cephalon, Inc. and Merck Serono; serves on speakers' bureaus for Novartis, Merck Serono, Schwarz Pharma, Boehringer Ingelheim, and Valeant Pharmaceuticals International; and receives research support from Novartis, German Research ministry (BMBF), Helmholtz Association (HelMA), and the European Union. Dr. Krüger has received funding for travel and speaker honoraria from UCB, Cephalon, Inc., Abbott, Takeda Pharmaceutical Company Limited, Teva Pharmaceutical Industries Ltd., and Medtronic, Inc.; serves as Associate Editor for the European Journal of Clinical Investigations, the Journal of Neural Transmission, and BMC Neurology; and receives research support from the German Research Council (DFG) and the Federal Ministry for Education and Research (BMBF).

Address correspondence and reprint requests to Dr. Rejko Krüger, Department for Neurodegenerative Diseases and Hertie Institute for Clinical Brain Research, and German Center for Neurodegenerative Diseases, University of Tübingen, Hoppe-Seyler-Str. 3, D-72076 Tübingen, Germany; rejko.krueger@uni-tuebingen.de

1. Meissner B, Kallenberg K, Sanchez-Juan P, et al. MRI lesion profiles in sporadic Creutzfeldt-Jakob disease. Neurology 2009; 72:1994-2001.

2. Mathews PM, Andermann F, Silver K, et al. Proton MR spectroscopic characterization of differences in regional brain metabolic abnormalities in mitochondrial encephalomyopathies. Neurology 1993;43:2484-2490. 


\section{Neurology}

\section{Rapid emergence of temporal and pulvinar lesions in MELAS mimicking Creutzfeldt-Jakob disease}

D. Weiss, K. Brockmann, T. Nägele, et al. Neurology 2011;77;914

DOI 10.1212/WNL.0b013e31822c6275

\section{This information is current as of August 29, 2011}

\section{Updated Information \& Services}

References

Subspecialty Collections

Permissions \& Licensing

Reprints including high resolution figures, can be found at: http://n.neurology.org/content/77/9/914.full

This article cites 2 articles, 2 of which you can access for free at: http://n.neurology.org/content/77/9/914.full\#ref-list-1

This article, along with others on similar topics, appears in the following collection(s):

Mitochondrial disorders; see Genetics/Mitochondrial disorders http://n.neurology.org/cgi/collection/mitochondrial_disorders_see_gene tics-mitochondrial_disorders

Prion disease; see Infections/prion

http://n.neurology.org/cgi/collection/prion_disease

Information about reproducing this article in parts (figures,tables) or in its entirety can be found online at:

http://www.neurology.org/about/about_the_journal\#permissions

Information about ordering reprints can be found online:

http://n.neurology.org/subscribers/advertise

Neurology ${ }^{\circledR}$ is the official journal of the American Academy of Neurology. Published continuously since 1951, it is now a weekly with 48 issues per year. Copyright Copyright @ 2011 by AAN Enterprises, Inc.. All rights reserved. Print ISSN: 0028-3878. Online ISSN: 1526-632X.

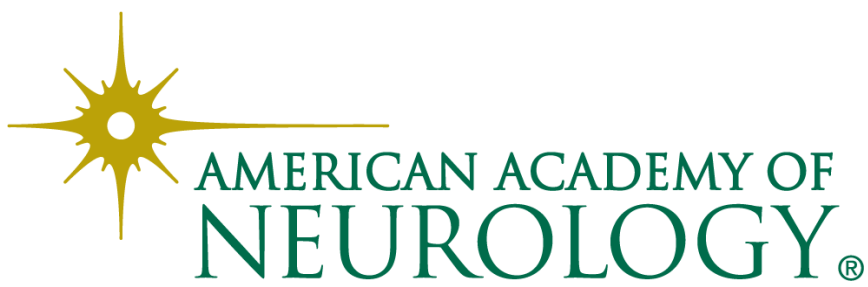

